\title{
Seasonal Variation in Fluoride Content in Groundwaters of Langtang Area, Northcentral Nigeria
}

\author{
H.U. Dibal*, W.N. Dajilak, , I.C. Lekmang, L.W. Nimze, E.Y. Yenne \\ Department of Geology, University of Jos, P.M.B 2084, Jos, Plateau State, Nigeria \\ *corresponding author: hassandibal@yahoo.com
}

Received: $24^{\text {th }}$ August, 2016

Accepted: $15^{\text {th }}$ February, 2017

\begin{abstract}
Thirty groundwater samples were collected at the peak of the rainy season and analysed for fluoride and other cations and anions in drinking water sources of Langtang area. For comparative purposes, thirty seven groundwater samples were collected in the dry season. The aim of the study was to determine variation in fluoride content with respect to the seasons. Fluoride in water was determined by the Ion Selective Electrode (ISE) and the cations by the Inductively Coupled Plasma Atomic Emission Spectrometry (ICP-AES). The anion (sulphate) was determined by Multi - Ion Colorimeter, bicarbonate and chloride by titration method. In addition fluorine content in aquifer materials from a borehole section were determined by Fusion method. The two seasons show variation in content of fluoride in groundwater. Fluoride content in groundwater is higher in the dry season ranging from $0.13-10.3 \mathrm{mg} / 1$ compared to the $0.06-4.60 \mathrm{mg} / \mathrm{l}$ values in the rainy season. Content of fluorine $(0.01 \mathrm{wt} \%)$ in the aquifer materials (sands) is low from depth of 0 to $7.95 \mathrm{~m}$. However, fluorine content increases with depth, from 7.95 to $10.60 \mathrm{~m}$ with concentration of $0.04 \mathrm{wt} \%, 0.05 \mathrm{wt} \%$ from 10.60 to $13.25 \mathrm{~m}$, and $0.07 \mathrm{wt} \%$ from 13.25 to $15.70 \mathrm{~m}$, the content of fluorine however, decreased at depth 15.70 to $18.55 \mathrm{~m}$ with concentration of $0.02 \mathrm{wt} \%$ even with fluorite mineral in the aquifer material at this depth. Dilution of fluoride ion as a result of rain input which recharges the aquifer may be the main reason for lower values recorded in the rainy season. Over fifty and sixty percent of waters in both dry and rainy season have fluoride concentration above the WHO upper limit of $1.5 \mathrm{mg} / \mathrm{l}$. Consumption of these elevated values of fluoride in groundwater of the study area, clearly manifests as symptoms of dental fluorosis.
\end{abstract}

Key words: groundwater, fluoride, fluorosis, aquifer

\section{Introduction}

Fluoride is well recognized as an element of public health concern (WHO, 2004). Though fluoride enters the body through foods, industrial exposure, drugs and cosmetics, drinking water is the major source $(75 \%)$ of daily intake of fluoride (Dissanayake, 1991). Fluoride is present universally in all waters but higher concentrations are found in groundwater, minerals and rocks. The optimal value of fluoride in drinking water is considered to be around $0.5-1.5 \mathrm{mg} / \mathrm{l}$ (WHO, $2004)$ and too little $(<0.5 \mathrm{mg} / \mathrm{l})$ or too much $(>1.5 \mathrm{mg} / \mathrm{l})$ can affect bone and teeth structure.
Higher concentration of fluoride also causes respiratory failure, fall in blood pressure and general paralysis. Continuous ingestion of nonfatal dose of fluorides causes permanent inhibition of growth (Ibrahim et al., 2011). From the epidemiological point of view both deficiency and excess of fluoride might be harmful.

The concentration of fluoride in groundwater depends on the geological, physical and chemical character of an aquifer, porosity and acidity of soil and rock, temperature and depth, groundwater age, well depth, hydrologic condition, residence time and geologic structure (Edmunds and Smedley, 
2005). Other factors of fluoride enrichment in groundwater are high evapo-transpiration rate, extensive and long term irrigation and heavyuse of fertilizer (Subba and Devadas, 2003). The presence of high $\mathrm{HCO}_{3}, \mathrm{Na}^{+}$and $\mathrm{pH}$ favours the release of fluoride from aquifer matrix into groundwater (Handa, 1975)

A variety of geochemical studies have been carried out on various aspect of fluoride in groundwater, particularly on the relationship between fluoride and some hydrogeochemical parameters as a result of water rock interaction in different geologic settings (Gaciri and Davies, 1993; Handa, 1975; Saxena and Ahmed, 2001). Rock-water interaction allows fluoride rich minerals in bedrocks to be decomposed resulting in fluoride enrichment in groundwater (Bardsen and Bjorvatin, 1995; Wenzel and Blums, 1992).The concentration of fluoride in groundwater is frequently proportional to the degree of water - rock interaction because fluoride basically originates from bedrock (Banks and Clement, 1995). Apambire et al., (1997) reported that the fluoride contained in micaceous mineral and their clay alteration product is a cause of fluoride enrichment in groundwater.

Inhabitants of Langtang depend on groundwater abstracted mainly from hand dug wells as source of drinking water, but elevated fluoride concentration has been reported in the area (Wongdem et al., 2002; Dibal et al., 2008, Dibal, et al., 2012). The aim of the study was to (a) determine the suitability of the groundwater for human consumption with respect to fluoride concentrations, and (b) evaluate the seasonal variation of fluoride concentration in groundwater of the study area.

\section{Description of the Study Area}

The study area is located between Latitudes $9^{\circ}$ $00^{1}$ and $9^{O} 11^{1} \mathrm{~N}$ and Longitudes $9^{\circ} 45^{1}$ and $9^{\circ}$ $54^{1} \mathrm{E}$ (Fig 1). The relief of the study area is defined by the elevated areas which are made up of the coarse to porphyritic hornblendebiotite granite (Pan-African Granites) and the lowlands made up of the migmatite and granite-gneiss (Dibal et al, 2015).

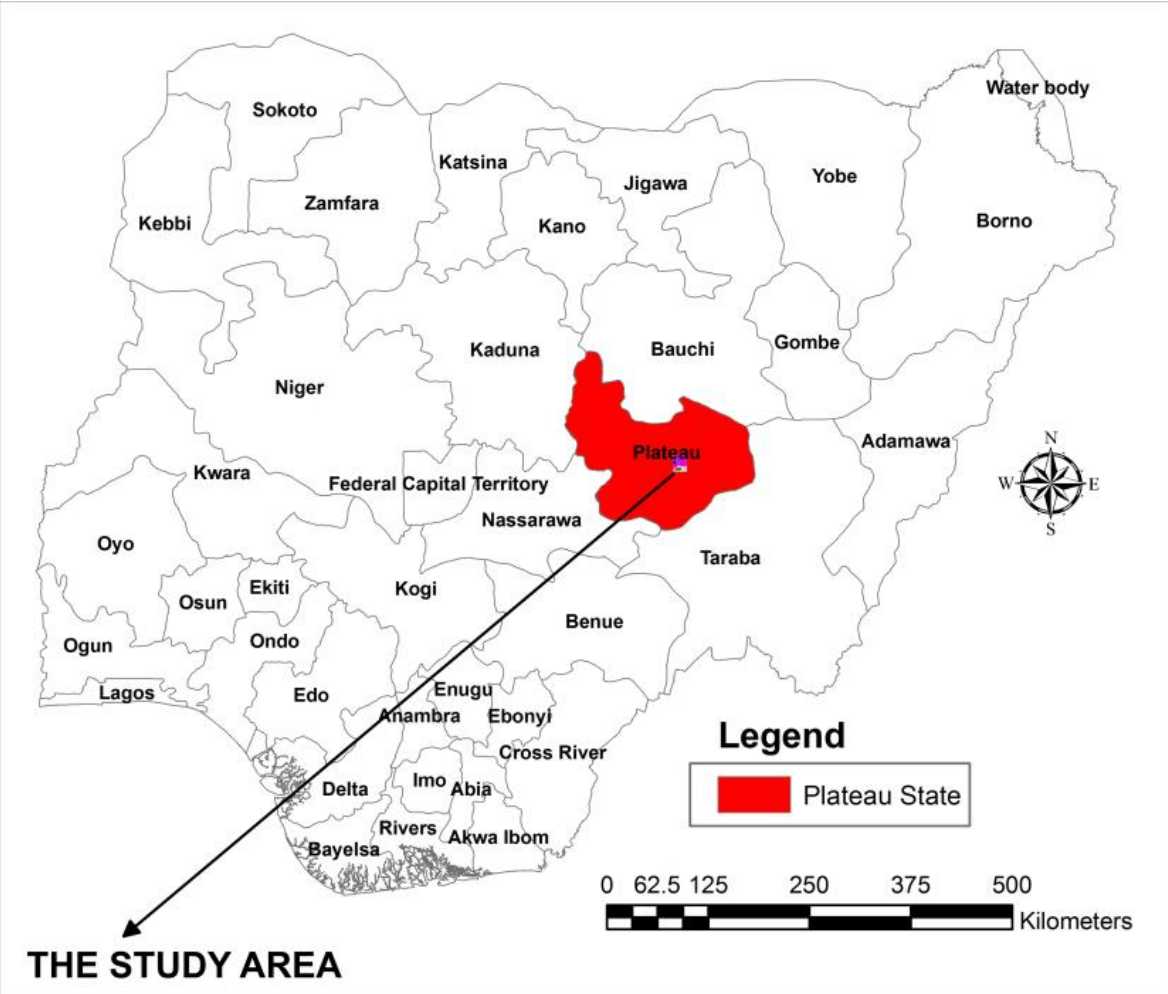

Fig.1. Location map of the Langtang area 
The main river draining the area is River Bapkwai which takes its course from the hills on the western side and flows towards the south east direction. Several other small streams drain the area which flow in the same direction. Over $60 \%$ of the area is entirely underlain by coarse to porphyritic granites intruded by rhyolites on the western part. Finegrained biotite granite and small scale intrusions of aplitic, pegmatitic and microgranites with xenoliths of the coarse to porphyritic granite are common. Small volcanic plugs are also common. The southern portion is underlain by migmatite with intrusions of an-orogenic granites which probably belong to the Younger Granite series of Nigeria (Dibal et al., 2012). Pegmatitic dykes have also intruded the migmatite (Fig. 2 and 3).

Surface water resources in the area consist mainly of streams, springs and ponds. The streams are seasonal; most of them have little or no water during the dry season. The ponds serve as a source of water supply to some villages especially during dry season (Plate I, see appendix).

The Bapkwai stream is the major stream that drains the entire study area. It is flooded in the rainy season and dries up during the dry season. During the dry season, the sands are scooped (Dibal et al., 2008) before water can be obtained (Plate II). Hydrogeologically, groundwater is found in three different aquifers; recently deposited alluvium found along river and stream channels, weathered overburden (soft overburden) aquifer and fractured crystalline aquifer.

Groundwater is found in the alluvium at depths of between $4-5 \mathrm{~m}, 10-15 \mathrm{~m}$ in the weathered overburden aquifer and $30-35 \mathrm{~m}$ in the fractured crystalline aquifer. In the dry season most of the hand-dug wells dry upand water is obtained from scooped water holes in streams and river sands (Plate II) (Dibal et al., 2012).
Some of the wells retain water even at the peak of the dry season (Plate III). Groundwater occurrence in the study area depends on physical characteristics of the underlying lithologic units such as thickness of weathered overburden and fractures. Igneous rocks typical of this area are not good rock material to form aquifer because of their relative impermeability. Therefore, such rocks store appreciable amount of ground water only when they are sufficiently fractured.

\section{Methodology - Field Sampling}

The field work was carried out during the peaks of the rainy seasons in August and in the dry season in February. The sampling points were first registered using Global Positioning System (GPS). Water samples from different boreholes, hand-dug wells, ponds, streams, a spring and a reservoir created by a dam in various locations were collected in $250 \mathrm{ml}$ plastic bottles to ensure adequate quantity for analysis. Thirty (30) drinking water sources including springs, boreholes, dam, ponds and hand-dug wells in order to evaluate the seasonal variation of fluoride concentration in the study area were collected. Two samples were collected at each point, one acidified with concentrated nitric acid to stabilize the concentration of trace elements and for cation analysis. The other un-acidified samples were collected for the determination of dissolved anions. Physical parameters of the water such as electrical conductivity, total dissolved solid, $\mathrm{pH}$ and temperature were measured with Electrical Conductivity meter (Oakton pH5/6 MV meter)and aquifer materials (soil and clay) from a drilled borehole at different depths were also collected for fluorine analyses respectively.

\section{Laboratory analysis - Water Analyses}

Major cations $\left(\mathrm{Ca}^{2+}, \mathrm{Mg}^{2+}, \mathrm{K}^{+}\right.$and $\left.\mathrm{Na}^{+}\right)$and trace elements were analyzed using the 
Inductively Coupled Plasma Optical Emission Spectrometry (ICP - OES), the composition of the anions $\left(\mathrm{Cl}^{-}\right.$, and $\left.\mathrm{HCO}_{3}{ }^{-}\right)$were determined by titration, $\mathrm{SO}_{4}{ }^{2-}$ and $\mathrm{NO}_{3}$ by Multi Ion Colorimeter and fluoride analyzed by Ion Selective Electrode (ISE).The laboratory analysis also involved the analysis of soil samples taken from a section of a borehole in the study area to determine its fluoride content. Content of fluorine in the aquifer materials (cuttings) were determined by the fusion method at the ACME Laboratory, Canada.

\section{Results and discussion}

\section{Physico-chemical Composition of Ground- water in Rainy and Dry Season}

A summary of physico-chemical composition of groundwater for both seasons is shown in Table 1 . The $\mathrm{pH}$ of rainy season water samples is lower ranging from $6.4-7.1$ than the dry season water samples ranging from 6.7 10.7.Thus, rainy season water samples are slightly acidic to neutral, while dry season water samples are slightly acidic to alkaline. This is expected because incongruent dissolution of silicate minerals in the dry season consumes $\mathrm{CO}_{2}$, thereby raising the $\mathrm{pH}$ of the water. The rainy season water samples have lower concentration of total dissolved solids $43-628 \mathrm{mg} / \mathrm{l}$ than dry season water samples $52-784 \mathrm{mg} / \mathrm{l}$. The temperature of the rainy season water samples have temperature ranging from $20-31^{\circ} \mathrm{C}$ compared to that of the dry season water $26-29^{\circ} \mathrm{C}$. This probably reflects the daily ambient temperature of the area at the time of sampling.

The concentrations of the cations $\mathrm{Na}^{+}, \mathrm{K}^{+}$ $\mathrm{Mg},{ }^{2+} \mathrm{Ca}^{2+}$ and the anions $\mathrm{Cl}^{-}$and $\mathrm{SO}_{4}{ }^{2-}$ are higher in rainy season water samples than those collected during dry season. One would expect that the reverse will be the case considering the dilution effect of rain input which recharges the groundwater. However, the anions $\mathrm{HCO}_{3},{ }^{-} \mathrm{F}^{-}$have lower concentrations in rainy season water samples than in dry season water samples. The higher concentration of sulphate may be the result of residential pollution. The higher concentration of the cations cannot easily be explained, since it is expected that dilution could have lowered their concentrations. Despite higher concentration of $\mathrm{Na}^{+}$in rainy season waters than dry season waters, $\mathrm{F}^{-}$concentration is lower in the rainy season.

\section{Variation in Fluoride Content in Groundwater of the Study Area}

The thirty (30) water samples collected during the rainy season and thirty seven(37) water samples for the dry season are presented in Table 2 and 3 respectively. The concentrations have also been presented as symbol point maps in Fig 2 and 3.The results of the fluoride concentration in the dry season water samples range from 0.36 to $10.30 \mathrm{mg} / \mathrm{l}$. Twenty (20) water samples had above $1.5 \mathrm{mg} / \mathrm{l}$ fluoride content which is above WHO (2004) permissible level and seventeen(17) water samples had below $1.5 \mathrm{mg} / \mathrm{l}$ the (WHO, 2004) recommended limit.

The results of the fluoride concentration in the rainy season water samples range from 0.06 to $4.10 \mathrm{mg} / \mathrm{l}$ with fluoride concentration in ten (10) water samples having over $1.5 \mathrm{mg} / 1$ (WHO, 2004) permissible level and eighteen (18) samples had below $1.5 \mathrm{mg} / \mathrm{l}$ (WHO, 2004) recommended limit. Two (2) water samples had fluoride concentration of $1.5 \mathrm{mg} / 1$ (WHO2004) recommended limit.

The highest fluoride concentration in ground water of the study area recorded during the dry season is $10.30 \mathrm{mg} / 1$, while the highest concentration recorded during the rainy season is $4.10 \mathrm{mg} / \mathrm{l}$. In general, fluoride concentration in dry season water samples is higher than those of rainy season. The low fluoride concentration recorded in the rainy season water samples may be the result of dilution from rain input which recharges the aquifer. 
Tab.1. A Summary of physico-chemical parameters of water collected during the rainy and dry season

\begin{tabular}{cccccccc}
\hline $\begin{array}{c}\text { Physico-chemical } \\
\text { Parameter }\end{array}$ & \multicolumn{3}{c}{ Dry Season } & \multicolumn{3}{c}{ Rainy season } & WHO Standards \\
Min. & Max. & Mean & Min. & Max. & Mean & $(\mathbf{2 0 0 4 )}$ \\
\hline $\mathrm{pH}$ & 6.40 & 10.70 & 8.50 & 6.30 & 7.20 & 6.27 & $6.5-8.5$ \\
$\mathrm{TDS}$ & 51.81 & 784.05 & 268.27 & 43 & 628 & 277 & 500 \\
$\mathrm{Temp}\left({ }^{\circ} \mathrm{C}\right)$ & 26 & 27.90 & 27.90 & 26 & 31 & 28.1 & - \\
$* \mathrm{EC}(\mu \mathrm{s} / \mathrm{cm})$ & & & & 82 & 1252 & 554 & - \\
$\mathrm{TH}$ & 11.09 & 407.06 & 120.11 & & & & 500 \\
$\mathrm{Ca}^{2+}$ & 5.91 & 117.10 & 30.31 & 12.84 & 128.5 & 50.56 & 75 \\
$\mathrm{Mg}^{2+}$ & 1.17 & 36.48 & 11.10 & 2.34 & 40.70 & 10.56 & 150 \\
$\mathrm{Na}^{+}$ & 5.07 & 40.37 & 90.98 & 7.78 & 198.85 & 58.8 & 200 \\
$\mathrm{~K}^{+}$ & 0.59 & 33.74 & 40.6 & 1.07 & 59.60 & 8.95 & - \\
$\mathrm{HCO}_{3}^{-}$ & 20.00 & 672.00 & 187.97 & 28.20 & 361.64 & 1.76 & - \\
$\mathrm{Cl}^{-}$ & 0.50 & 75.00 & 17.59 & 28.36 & 184.34 & 76.3 & 500 \\
$* \mathrm{NO}_{3}^{-}$ & & & & 2.6 & 8.6 & 5.03 & - \\
$\mathrm{SO}_{4}^{2-}$ & 0.50 & 51.00 & 8.10 & 13.80 & 99.00 & 36.7 & 400 \\
$\mathrm{~F}^{-}$ & 0.12 & 10.30 & 2.47 & 0.06 & 4.10 & 1.36 & 1.5 \\
\hline
\end{tabular}

*Note: $\mathrm{EC}$ and $\mathrm{NO}_{3}{ }^{-}$were not measured in the Dry season

Tab.2. Results of fluoride concentration in water samples collected during rainy season.

\begin{tabular}{|c|c|c|c|}
\hline Sample ID & \multicolumn{2}{|c|}{ Coordinates } & Fluoride concentration $(\mathrm{mg} / \mathrm{l})$ \\
\hline WD1 & $\mathrm{N} 9^{\circ} 04 \cdot 33$ & $\mathrm{E}^{\circ} 49.05$ & 0.18 \\
\hline WD2 & $\mathrm{N} 9^{\circ} 04 \cdot 39$ & $\mathrm{E}^{\mathrm{O}} 48.57$ & 0.69 \\
\hline WD3 & $\mathrm{N} 9^{\circ} 06.27$ & $\mathrm{E} 9^{\circ} 48.26$ & 0.06 \\
\hline WD4 & $\mathrm{N} 9^{\circ} 08.16$ & $\mathrm{E}^{\mathrm{O}} 49.08$ & 0.66 \\
\hline WD5 & N9 $9^{\circ} 08 \cdot 24$ & $\mathrm{E}^{\mathrm{O}} 49.20$ & 2.00 \\
\hline WD6 & $\mathrm{N} 9^{\circ} 05.06$ & $\mathrm{E}^{\mathrm{O}} 45.33$ & 3.30 \\
\hline WD7 & $N 9^{\circ} 06.05$ & $\mathrm{E}^{\circ} 46.17$ & 0.53 \\
\hline WD8 & $\mathrm{N} 9^{\circ} 07.15$ & $\mathrm{E}^{\circ} 47.10$ & 1.10 \\
\hline WD9 & $\mathrm{N} 9^{\circ} 07.17$ & E9 97.15 & 1.50 \\
\hline WD10 & $\mathrm{N} 9^{\circ} 07.18$ & $\mathrm{E}^{\circ} 47.16$ & 1.20 \\
\hline WD11 & $\mathrm{N} 9^{\circ} 07.45$ & E9 47.37 & 0.20 \\
\hline WD12 & N9 $9^{\circ} 07.28$ & $\mathrm{E}^{\mathrm{O}} 48.10$ & 0.74 \\
\hline WD13 & $\mathrm{N} 9^{\circ} 70.37$ & E9 47.59 & 0.41 \\
\hline WD14 & $\mathrm{N} 9^{\circ} 08.05$ & $\mathrm{E}^{\mathrm{O}} 47.44$ & 0.45 \\
\hline WD15 & $\mathrm{N} 9^{\circ} 08.03$ & $\mathrm{E}^{\mathrm{O}} 47.46$ & 0.73 \\
\hline WD16 & $\mathrm{N} 9^{\circ} 08.06$ & E9 $9^{\circ} 47.45$ & 2.20 \\
\hline WD17 & $\mathrm{N} 9^{\circ} 08.49$ & $\mathrm{E} 9^{\circ} 47.35$ & 1.10 \\
\hline WD18 & $\mathrm{N} 9^{\circ} 08.50$ & $\mathrm{E}^{\circ} 47.39$ & 2.10 \\
\hline WD19 & N9 $9^{\circ} 09.45$ & $\mathrm{E}^{\mathrm{O}} 47.18$ & 3.60 \\
\hline WD20 & N9 $9^{\circ} 11.45$ & $\mathrm{E}^{\circ} 46.11$ & 4.10 \\
\hline WD21 & $\mathrm{N} 9^{\circ} 08.50$ & $\mathrm{E}^{\circ} 48.13$ & 0.41 \\
\hline WD22 & $\mathrm{N} 9^{\circ} 09.01$ & $\mathrm{E}^{\mathrm{O}} 48.20$ & 1.50 \\
\hline WD23 & $\mathrm{N} 9^{\circ} 08.59$ & $\mathrm{E}^{\circ} 48.47$ & 1.70 \\
\hline WD24 & $\mathrm{N} 9^{\circ} 09.08$ & $\mathrm{E}^{\circ} 48.47$ & 1.90 \\
\hline WD25 & $\mathrm{N} 9^{\circ} 09.31$ & $\mathrm{E}^{\circ} 48.21$ & 0.20 \\
\hline WD26 & $\mathrm{N} 9^{\circ} 09.26$ & $\mathrm{E}^{\mathrm{O}} 47.52$ & 0.61 \\
\hline WD27 & $\mathrm{N} 9^{\circ} 10.59$ & $\mathrm{E}^{\mathrm{O}} 51.36$ & 0.46 \\
\hline WD28 & $\mathrm{N} 9^{\circ} 10.54$ & E9 49.06 & 0.95 \\
\hline WD29 & $\mathrm{N}^{\mathrm{O}} 10.57$ & $\mathrm{E}^{\mathrm{O}} 48.48$ & 3.70 \\
\hline WD30 & $\mathrm{N} 9^{\circ} 11.00$ & $\mathrm{E}^{\circ} 48.18$ & 3.10 \\
\hline
\end{tabular}


Tab.3. Results of fluoride concentration water samples collected during the dry season.

\begin{tabular}{|c|c|c|c|}
\hline Sample ID & \multicolumn{2}{|c|}{ Co-ordinates } & fluoride concentration $(\mathrm{mg} / \mathrm{l})$ \\
\hline HD1 & $\mathrm{N} 9^{\circ} 01.030$ & $\mathrm{E} 9^{\circ} 46.072$ & 0.7 \\
\hline HD2 & $\mathrm{N} 9^{\mathrm{O}} 10.664$ & $\mathrm{E} 9^{\mathrm{O}} 45.726$ & 1.8 \\
\hline HD3 & $\mathrm{N} 9^{\mathrm{O}} 10.625$ & $\mathrm{E} 9^{\mathrm{O}} 45.275$ & 0.69 \\
\hline HD4 & $\mathrm{N} 9^{\circ} 08.377$ & E9 46.887 & 2.23 \\
\hline HD5 & $\mathrm{N} 9^{\circ} 09.394$ & E9 47.185 & 3.37 \\
\hline HD6 & $\mathrm{N} 9^{\circ} 10.060$ & $\mathrm{E} 9^{\circ} 46.080$ & 3.75 \\
\hline HD7 & $\mathrm{N} 9^{\mathrm{O}} 10.060$ & $\mathrm{E} 9^{\mathrm{O}} 46.800$ & 1.28 \\
\hline HD8 & $\mathrm{N} 9^{\mathrm{O}} 09.216$ & $\mathrm{E} 9^{\mathrm{O}} 50.030$ & 4.00 \\
\hline HD9 & $\mathrm{N} 9^{\circ} 10.416$ & $\mathrm{E} 9^{\mathrm{O}} 50.687$ & 3.22 \\
\hline HD10 & $\mathrm{N} 9^{\circ} 11.017$ & E9 50.551 & 4.87 \\
\hline HD11 & $\mathrm{N} 9^{\mathrm{O}} 10.914$ & $\mathrm{E} 9^{\mathrm{O}} 49.486$ & 3.1 \\
\hline HD12 & $\mathrm{N} 9^{\mathrm{O}} 09.540$ & $\mathrm{E} 9^{\mathrm{O}} 48.027$ & 3.86 \\
\hline HD13 & $\mathrm{N} 9^{\mathrm{O}} 10.234$ & $\mathrm{E} 9^{\mathrm{O}} 47.880$ & 3.69 \\
\hline HD14 & N9 ${ }^{\circ} 10.907$ & $\mathrm{E}^{\circ} 48.088$ & 3.80 \\
\hline HD15 & $\mathrm{N} 9^{\circ} 09.431$ & $\mathrm{E}^{\mathrm{O}} 47.205$ & 3.00 \\
\hline HD16 & $\mathrm{N} 9^{\mathrm{O}} 07.832$ & $\mathrm{E}^{\circ} 48.429$ & 0.12 \\
\hline HD17 & $\mathrm{N} 9^{\circ} 06.508$ & $\mathrm{E}^{\mathrm{O}} 48.401$ & 2.30 \\
\hline HD18 & $\mathrm{N} 9^{\circ} 06.526$ & $\mathrm{E}^{\mathrm{O}} 47.895$ & 0.65 \\
\hline HD19 & $\mathrm{N} 9^{\circ} 07.348$ & $\mathrm{E}^{\circ} 49.973$ & 0.89 \\
\hline HD20 & $\mathrm{N} 9^{\mathrm{O}} 05.759$ & $\mathrm{E}^{\circ} 48.609$ & 0.54 \\
\hline HD21 & $\mathrm{N} 9^{\circ} 08.502$ & $\mathrm{E}^{\mathrm{O}} 48.127$ & 10.30 \\
\hline HD22 & $\mathrm{N} 9^{\circ} 05.665$ & E9 50.664 & 1.26 \\
\hline HD23 & $\mathrm{N} 9^{\circ} 06.496$ & $\mathrm{E}^{\mathrm{O}} 52.473$ & 0.36 \\
\hline HD24 & $\mathrm{N} 9^{\circ} 07.000$ & $\mathrm{E}^{\mathrm{O}} 50.617$ & 1.78 \\
\hline HD25 & $\mathrm{N} 9^{\circ} 07.352$ & E9 50.564 & 1.45 \\
\hline HD26 & $\mathrm{N} 9^{\circ} 08.469$ & $\mathrm{E}^{\circ} 52.226$ & 0.78 \\
\hline HD27 & $\mathrm{N} 9^{\circ} 09.673$ & $\mathrm{E}^{\mathrm{O}} 48.905$ & 1.17 \\
\hline HD28 & $\mathrm{N} 9^{\mathrm{O}} 05.108$ & $\mathrm{E} 9{ }^{\circ} 48.811$ & 3.38 \\
\hline HD29 & $\mathrm{N} 9^{\circ} 04.716$ & $\mathrm{E}^{\mathrm{O}} 48.694$ & 0.80 \\
\hline HD30 & $\mathrm{N} 9^{\circ} 03.021$ & $\mathrm{E}^{\circ} 49.314$ & 1.72 \\
\hline HD31 & $\mathrm{N} 9^{\circ} 03.325$ & $\mathrm{E}^{\circ} 49.078$ & 1.39 \\
\hline HD32 & $\mathrm{N} 9^{\circ} 06.025$ & $\mathrm{E}^{\mathrm{O}} 45.502$ & 6.36 \\
\hline HD33 & $N 9^{\circ} 06.265$ & $\mathrm{E}^{\mathrm{O}} 46.478$ & 1.44 \\
\hline HD34 & $\mathrm{N} 9^{\circ} 06.278$ & $\mathrm{E}^{\circ} 47.189$ & 1.40 \\
\hline HD35 & $\mathrm{N} 9^{\circ} 07.273$ & $\mathrm{E}^{\circ} 47.186$ & 1.44 . \\
\hline HD36 & $\mathrm{N} 9^{\circ} 06.506$ & $\mathrm{E}^{\mathrm{O}} 47.410$ & 3.89 \\
\hline HD37 & $\mathrm{N} 9^{\circ} 07.380$ & E9O 47.515 & 1.28 \\
\hline
\end{tabular}




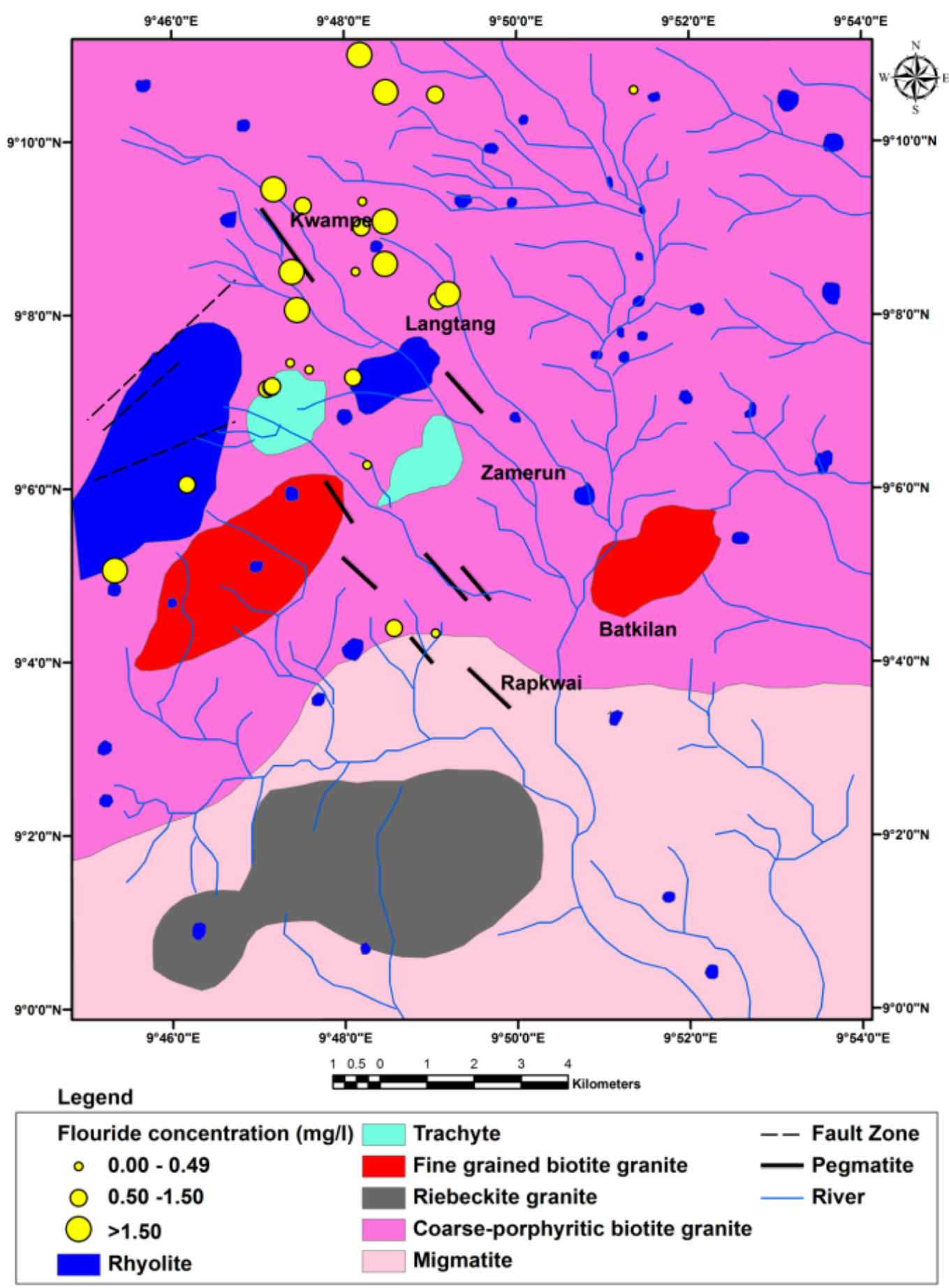

Fig.2. Geological map and spatial distribution of fluoride content in rainy season water samples of the study area 


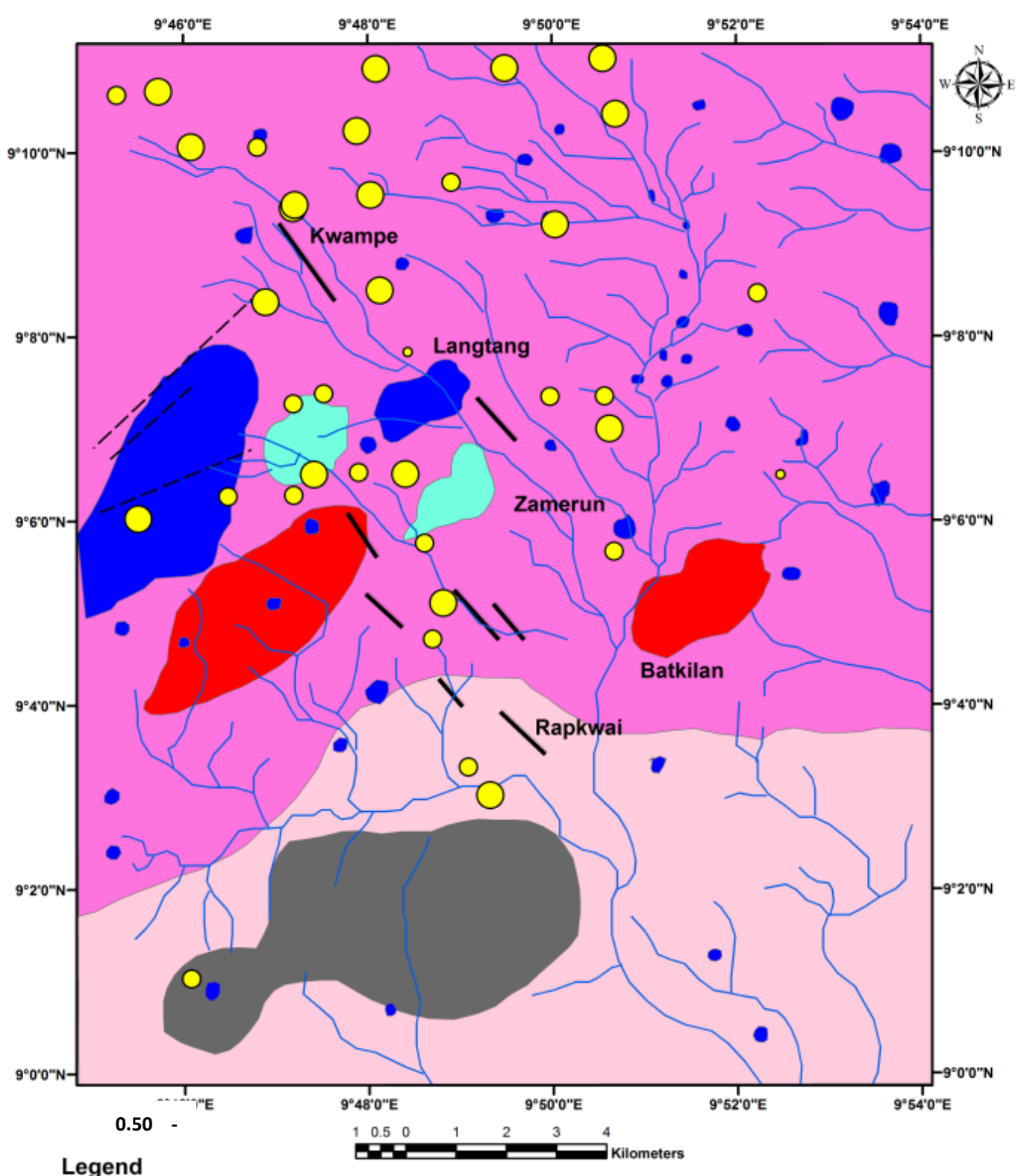

Legend

Flouride concentration (mg/l)

○ $0.00-0.49$

Trachyte

- - Fault Zone

$0.50-1.50$

Fine grained biotite granite

- Pegmatite

$\bigcirc>1.50$

Riebeckite granite River

Rhyolite

Coarse-porphyritic biotite granite Migmatite

Fig.3. Geological map and spatial distribution of fluoride content in dry season water samples of the study area

\section{Groundwater Types in the Study Area}

Piper diagrams (Piper, 1944) for rainy and dry season water samples are shown in Figure 4 and 5 for groundwater types. $45 \%$ of rainy season water samples plot within the $\mathrm{Ca}+\mathrm{Mg}$
$-\mathrm{HCO}_{3}$ water type and the remaining $55 \%$ plot within the middle of the diamond suggesting mixed groundwater types, where no cation or anion is dominant. The dry season water samples plot within the $\mathrm{Ca}+\mathrm{Mg}-\mathrm{HCO}_{3}$ and $\mathrm{Na}+\mathrm{K}-\mathrm{HCO}_{3}$ region. A closer look at the 
dry season plot indicates evolution of the groundwater from the $\mathrm{Ca}+\mathrm{Mg}-\mathrm{HCO}_{3}$ to the $\mathrm{Na}-\mathrm{HCO}_{3}$ water type (Dibal, 2015)

\section{Concentration of Fluorine in Aquifer Material}

Table 3 shows the content of fluorine in aquifer materials (soil and clay) from a section of a borehole in the study area. Content of fluorine in the aquifer materials is the same from 0 to $7.95 \mathrm{~m}$ depth with concentration of $0.01 \mathrm{wt} \%$. However, fluorine content increased with depth, from 7.95-10.60 $\mathrm{m}$ with concentration of $0.04 \mathrm{wt} \%, 10.60-13.25 \mathrm{~m}, 0.05$ wt $\%$ and 13.25-15.70 m, $0.07 \mathrm{wt} \%$. The content of fluorine however, decreased at depth 15.70-18.55m with concentration of 0.02 wt $\%$ even with fluorite mineral in the aquifer material at this depth. Dibal et al, (2015), had earlier reported concentration of fluorine in rocks of the study area (rhyolite, riebeckite granites and trachyte) to be high.

\section{Distribution of Fluoride According to Drinking Water Sources of the Study Area}

Out of the 37 water samples collected during the dry season from different drinking water sources (hand-dug wells, boreholes, streams, ponds and a spring) results showed that the concentration of fluoride in the various water sources vary. Waters collected from scooped sands along stream channels have lower fluoride concentration as against those in handdug wells and boreholes. These low concentrations of fluoride in the stream bed are both recorded in dry and rainy season. Reason for low concentration in the dry season is probably lack of time for waters to interact with fluorine bearing minerals. The similarity in levels of fluoride in both boreholes and hand dug-well shows that depths of water sources in the study area do not determine concentration of fluoride. However, Boyle and Chagnon (1995) established the increase of fluoride concentration with depth. The 30 water samples collected during the rainy season from different drinking water sources (hand-dug wells, boreholes, reservoir, spring, and pond), show fluoride concentration in the waters ranging from $0.06-4.10 \mathrm{mg} / \mathrm{l}$ with a mean of $1.4 \mathrm{mg} / \mathrm{l}$. Waters collected from some boreholes and a pond have much higher concentration of fluoride than waters collected from some hand dug wells. The low concentration of fluoride in some hand dug wells may be the result of dilution from rain water recharging the aquifer. Fluoride concentration in some of the hand dug wells are however, higher than those in some boreholes. However the highest fluoride concentration recorded $(4.10 \mathrm{mg} / \mathrm{l})$ is from a borehole and the lowest concentration of $0.06 \mathrm{mg} / \mathrm{l}$ is from a well but there are similarities in fluoride concentration between some hand dug wells, boreholes and the pond. This also, may indicate that depth does not determine the concentration of fluoride in the water sources during the rainy season. The natural concentration of fluorine in rocks probably varies from place to place and this may be another factor influencing the content of fluoride in water samples from different sites.

Sources and Geochemistry of Fluoride in the Waters of the Study Area

According to Dibal et al., (2012), negative correlation between fluoride and sulphate, fluoride and nitrate, fluoride and phosphate and poor correlation between fluoride and nitrate, fluoride and chloride rules out the possibility of anthropogenic source of fluoride in the waters of the study area. But positive correlation between fluoride and magnesium, and poor but positive correlation between fluoride and lithium indicate micas within the host rock and the pegmatites may be leaching fluoride into the waters. However, the principal rocks hosting fluorine mineral(fluorite and riebeckite) are the rhyolite and riebeckite granites (Dibal, 2015). 
In the present study, the source of fluoride in the groundwater is multiple, but associated to the earlier minerals (fluorite, riebeckite) reported by Dibal et al, 2015. Although, only very few percentages of fluorite have been seen in the sections of the borehole cuttings, it is the principal mineral responsible for leaching fluorine into groundwater (Handa, 1975; Kundu, et al., 2001; Ramamohana et al., 1993; Valenzuela-Vasquez et al., 2006). The high concentration of fluorine at different depth of the borehole indicates contribution from biotite and hornblende. Korting, (1972) said that about $80-90 \%$ of fluorides are contained in muscovite, illite and related minerals of the mica group. Nordstrom and Jenne (1977); Chae et al., (2008) and Liet al.,(2003)have suggested likely sources of fluoride in groundwater to be the weathering of biottite.

Hence the major reason for elevated groundwater fluoride concentration in the study area is due to the weathering of rocks and water-rock interaction which when in contact with water of high alkalinity are released into groundwater by hydrolysis.

\section{Piper Diagram}
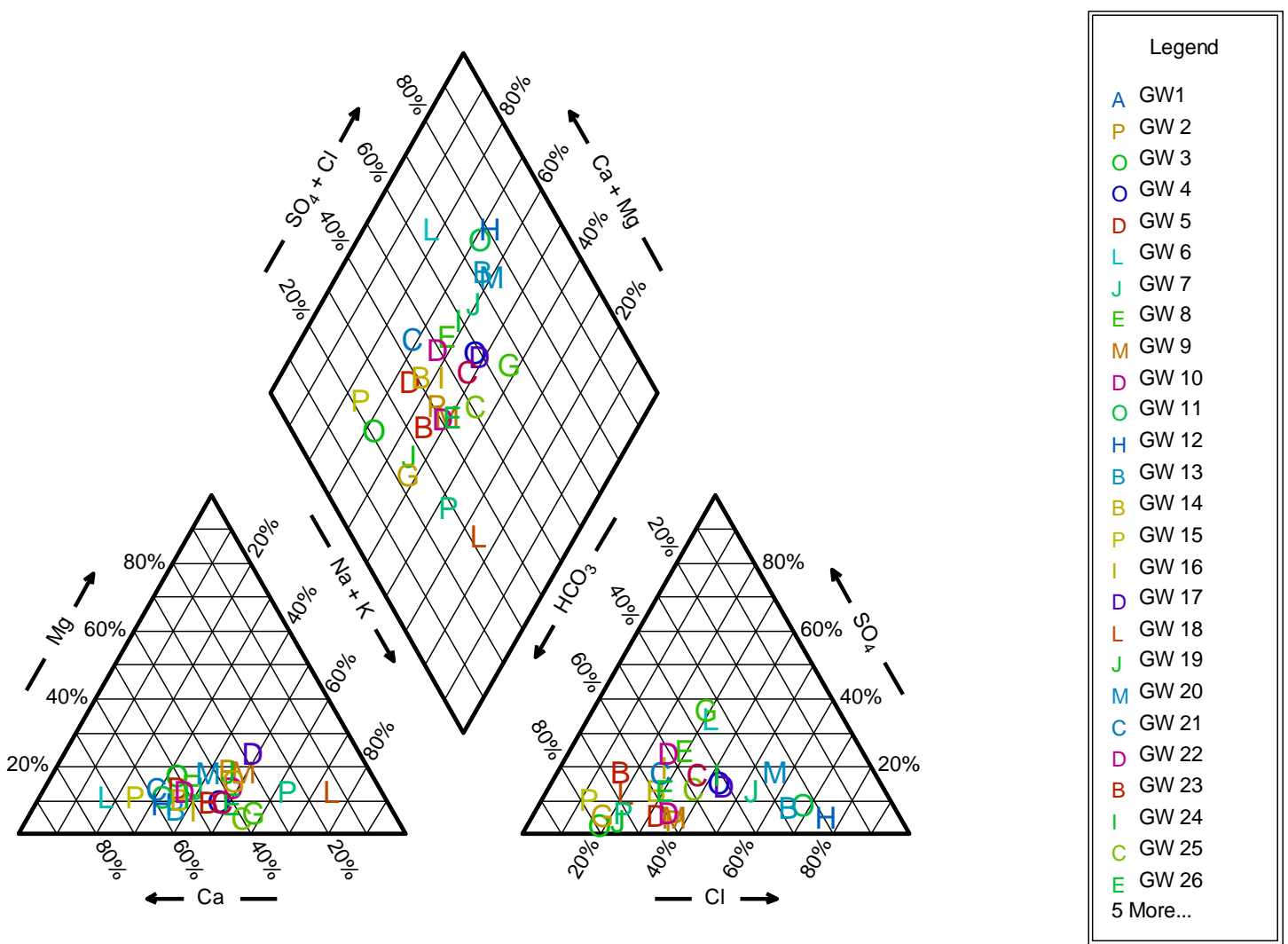

Fig.4. Piper diagram for rainy season water samples suggesting groundwater type 


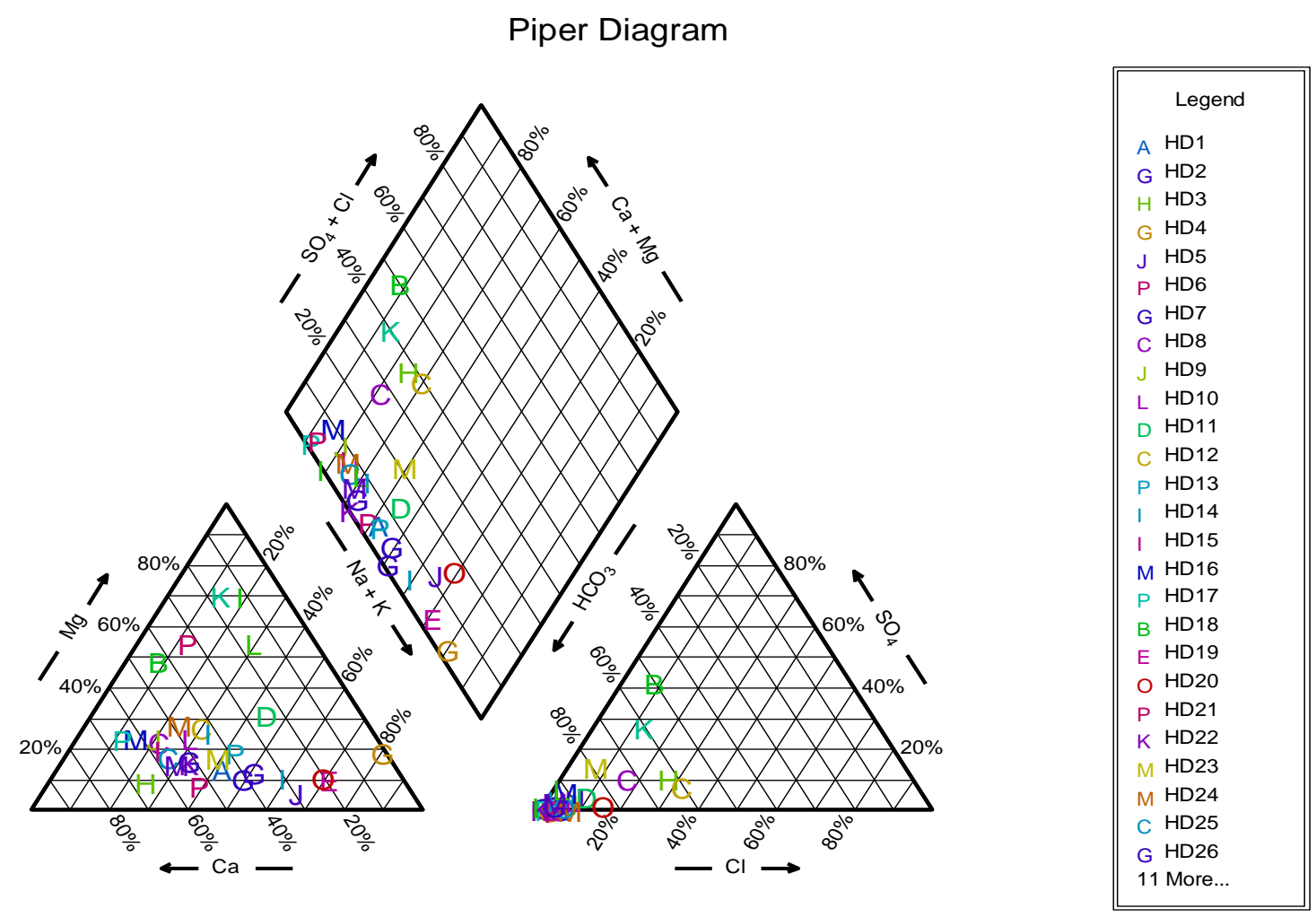

Fig.5. Piper diagram for dry season water samples suggesting groundwater type

Tab.3. Percentages of fluorine content in aquifer materials (cuttings) from a section of a borehole in the study

\begin{tabular}{cccc}
\hline \multicolumn{3}{c}{ area } & Wt (\%) Fluorine \\
\hline Sample ID & Soil depth & Soil type & $<0.01$ \\
WDI & $0-2.65 \mathrm{~m}$ & Sandy & $<0.01$ \\
WD3 & $2.65-5.30 \mathrm{~m}$ & Sandy & $<0.01$ \\
WD4 & $5.30-7.95 \mathrm{~m}$ & Sandy & $<0.04$ \\
WD5 & $7.95-10-60 \mathrm{~m}$ & Sandy & $<0.05$ \\
WD6 & $10.60-13.25 \mathrm{~m}$ & Sandy & $<0.07$ \\
WD7 & $13.25-15.70 \mathrm{~m}$ & Sandy & $<0.02$ \\
\hline
\end{tabular}

Health implications of Fluoride in Drinking Water Sources of the Study Area

Out of the 37 water samples collected during the dry season from different drinking water sources, 17 (45\%) water sources have fluoride concentration between $0.5-1.5 \mathrm{mg} / \mathrm{l}$ WHO (2004) lower and upper limit. 54\% are above the $1.5 \mathrm{mg} / \mathrm{l}$ recommended by the $\mathrm{WHO}(2004)$.
$1 \%$ of water sources have fluoride concentration lower than $0.5 \mathrm{mg} / \mathrm{l} \mathrm{WHO}$ (2004) recommended for the prevention of dental carries.

Out of the 30 water samples collected during the rainy season from different drinking water sources, 10 water sources $(33 \%)$ have fluoride concentration above $1.5 \mathrm{mg} / \mathrm{l}$ WHO 2004 recommended limit, 18 (60\%) water 
sources have fluoride concentration below $1.5 \mathrm{mg} / 1$ and $2(1 \%)$ water sources have fluoride concentration of $1.5 \mathrm{mg} / 1$. Demographic studies earlier carried out in the area (Wongdem et al, 2002) on sampled population by age group $(\mathrm{n}=473)$ has established that $(28.6 \%)$ of the population aged $10-19$ years has the highest frequency of mottling with a uniform decrease towards the age group $70-79$ years. There is however, no discrimination found between these age groups with respect to sex. The study also established cases of genu valgum (bowing of legs) in the lower ages of between $6-9$ years (Wongdem et al 2002). Chronic manifestation of dental fluorosis in school children with greater manifestation in school children aged between $7-11$ years has also been reported by Dibal et al 2008 and 2015). Plate V and VI are manifestations of dental fluorosis in a woman aged 70 years and a man aged 30 years. The upper incisors have been removed from the man in Plate VI.

\section{Conclusions}

A comparison of the results of fluoride concentrations obtained during the rainy and dry season revealed that the concentration obtained in groundwaters of the study area during the dry season is higher than that obtained during the rainy season. This indicates that dilution is caused by rainwater that recharges the aquifer and reduces the content of fluoride.

No clear variation in fluoride content is seen with respect to the sources of water (boreholes, hand dug wells, etc) in the study area both in dry and rainy season.

Weathering and water-rock interaction are the principal processes that leach fluorine into the groundwater of the study area both in the dry and rainy season. The principal groundwater types are the $\mathrm{Ca}+\mathrm{Mg}-\mathrm{HCO} 3$ and $\mathrm{Na}-\mathrm{HCO} 3$ in the dry season and the mixed groundwater types characterize the rainy season. All water types have good association with fluoride content.

Cuttings from the aquifer (sands) show variation in fluorine content with lower concentration at both the top and the bottom soils and higher between the top and the bottom

Out of the 30 water samples collected during the rainy season from different drinking water sources, $33 \%$ have fluoride concentration above $1.5 \mathrm{mg} / \mathrm{l}$ WHO 2004 recommended limit, $60 \%$ of water sources have fluoride concentration below $1.5 \mathrm{mg} / \mathrm{l}$ and $1 \%$ have fluoride concentration of $1.5 \mathrm{mg} / \mathrm{l}$

Inhabitants of Langtang area show manifestation of fluoride toxicity in form of dental fluorosis and bowing of legs (Genu Valgum) in the age groups 6 to 9 years and dental fluorosis in age group $10-19$ years and decreases uniformly towards the older (60 to 79 ) ages.

No remediation for fluoride in drinking water has been suggested for the inhabitants yet, but the practice of storing water in clay pot has been in use over the years.

\section{Acknowledgement}

We are sincerely grateful to the various reviewers, especially to Professor Mwakio Tole, who made a lot of inputs to bring the paper to what it is. Also, to the Langtang Community for giving to us access to their private wells. To the staff of ACME Laboratories Vancouver, Canada, for analyzing our samples promptly and lastly to Professor Theo Clavell Davies who never gets tired of encouraging us.

\section{References}

Apambire, W.B., Boyle, D.R and Michael, F.A (1997): Geochemistry, Genesis and health implication of fluoride in groundwater in the Upper region of Ghana. Environmental Geology, 33, pp 13-24. 
Banks, O. and Clement, R. (1995): Natural concentration of Major and Trace elements in some Norwegian bedrock groundwater. Geological surveys of Norway, N7002 Trondherm - Norway. Pp 1-4.

Bardsen, A and Bjorvatin, K.A (1995): Variability of fluoride content of subsurface water reservoirs. Acta Odentol. Scand. 54, pp 343-347.

Boyle, D.R and Chagnon, M. (1995): An incidence of skeletal fluorosis associated with groundwater of the maritime Carboniferous basin, Gaspe Region, Quebec, Canada. Environmental Geochemistry and Health 17, pp 5-12.

Chae, G.Y., Seong, T.M., Bernhard, K., Kyoung, K. and Seong-Yong, K.(2007): Fluoride geochemistry in bed rock groundwater of South Korea. Science of the Total Environment, 385, pp 272-283.

Dibal, H.U., Lekmang, I.C and Lar, U.A (2008): Dental fluorosis from drinking water consumption in Langtang town, plateau state, Nigeria. Continental Journal of Earth Sciences 3, pp77-82.

Dibal, H.U, Schoeneich, K., Garba, I., Lar, U.A and Bala, E.A (2012): Occurrence of fluoride in the drinking waters of Langtang area, North-central Nigeria. Vol 4, No. 11, pp 1116- 1126.

Dibal, H. U (2015): Concentration of fluoride and incidence of fluorosis in Northern Nigeria with emphasis on Langtang area. Unpublished Ph.D Dissertation, Department of Geology, Ahmadu Bello University, Zaria.

Dissanayake. C.B. (1991): The Fluoride problem in ground waters of Sri Lanka.Environmental Problems and Health. International Journal and Environmental Studies 19, pp. 195.

Edmunds W.M and Smedley, P.L (2005): Fluoride in Natural Waters In: Selinus, O et al (Ed) Essential of Medical Geology, Springer. Pp 311 - 336
Gaciri, S.J and Davies T.C (1993): The occurrence and geochemistry of fluoride in some natural waters of Kenya. Journal of Hydrology. 143, pp395-412.

Handa, R.K (1975): Geochemistry and genesis of fluoride-containing Groundwater in India, GW, 13, pp 275-281.

Ibrahim, M., Asimrasheed, M., Sumalatha, M. and Prakash, P. (2011): Effects of fluoride contents in groundwater. A review: Int. Jour. of Pharm. Appl. Vol 2, pp128-134.

Kortting, S. (1972): Fluorine 9B-90. In Wedepohl, K.H (ed). Handbook of Geochemistry. Springer-Verlag.

Kundu, N., Panigrahi, M.K, Tripathy S., Munshi S., Powell, M.A and Hart, B.R (2001): Geochemical appraisal of fluoride contamination of groundwater in the Nayagarh District of Orissa, India.

Li, Z., Tainoshi, Y., Shirashi, K. and Owada, M. (2003): Chemical characteristics of fluoride-bearing biotite of Early Paleozoic Plutonic rocks from the Sor Rondane Mountains, East Antartica. Journal of Geochemistry, 37, pp 145-161.

Nordstrom, D.K and Jenne, E.A (1977): Fluorite solubility in selected geothermal waters. Geochemical Cosmochima Acta, 41, pp 175-188.

Piper, A.M (1994): A graphic procedure in the geochemical interpretation of water analyses. American Geophysical Union Papers, Hydrology. Pp 914-923.

Ramamohana, R.N.V, Rao, N., Prakash, R.S.K and Schuiling, R.D (1993): Fluoride distribution in water of Nalgonda District, Andhra Pradesh, India. Environ Geol.

Saxena, V.K and Ahmed, S. (2001). Dissolution of fluoride in groundwater: Groundwater-rock interaction study. Env.Geol. 40, pp 1084-1087.

Subba, R. and Devadas, D. (2003): Fluoride incidence in groundwater in a developing area of Guntur district, Andhra Pradesh India, J. Appl. Geochem 5, pp 94-100. 
Valenzuela-Vasquez, L., Ramirez-Hernnandez, J., Yeyes-Lopez, J., Sol-Uribe, A. and Lazaro-Mancilla, O. (2006): The origin of fluoride in groundwater supply to Hermosillo City, Sonora, Mexico. Environ. Geol. 56, pp 1707-1719.

Wenzel, W.W and Blums, W.E.H (1992):

Fluoride specification and mobility in fluoride-contaminated soil and minerals. Soil Sci. 152, pp 357-364.
Wongdem, J.G, Aderinokun, G.A, Sridhar, M.R and Selkur, S. (2002). Prevalence and distribution pattern of enamel fluorosis in Langtang Town. African Journal of Medical Science Fluoride, 35, pp 120-135.

WHO (2004): Guidelines for drinking Water quality. $3^{\text {rd }}$ edition, World Health Organization, Geneva.

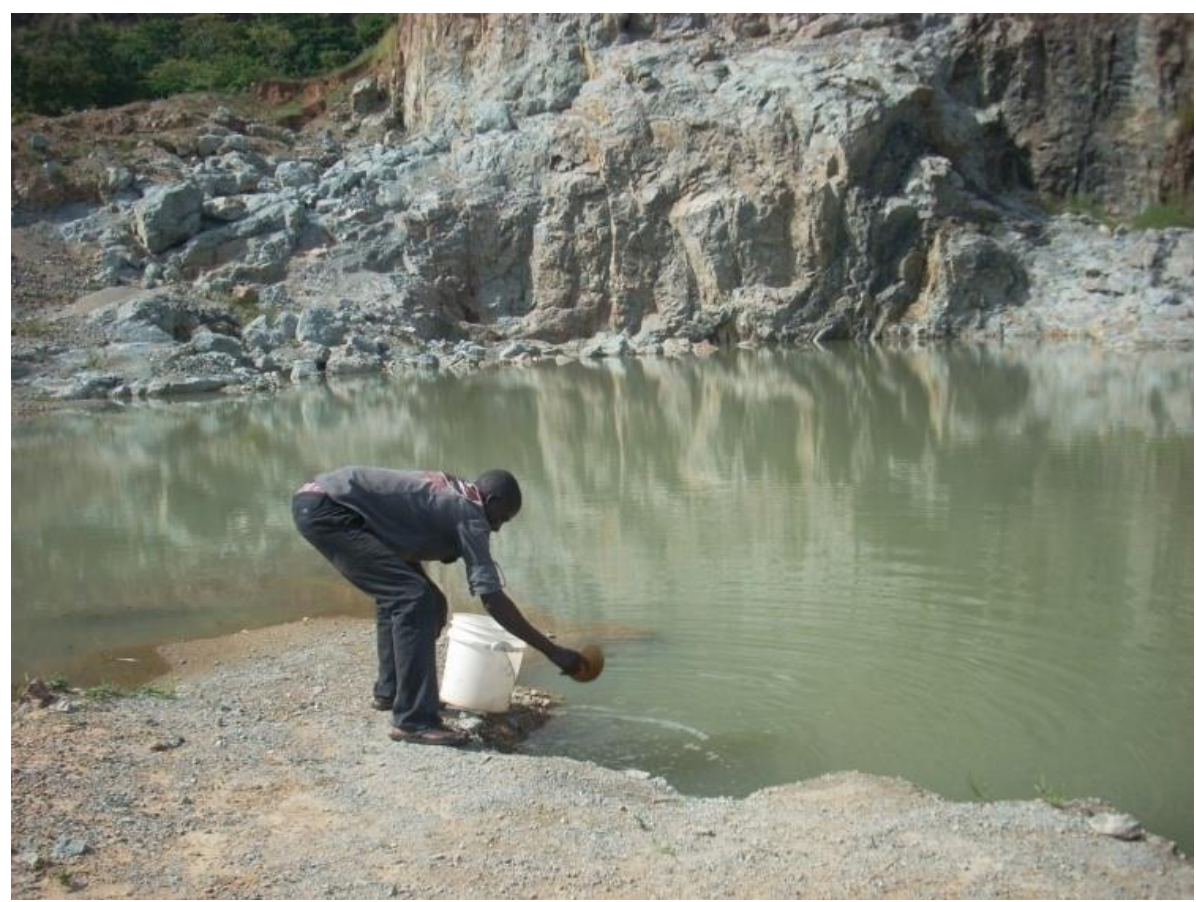

Plate I: Water pond from a quarried section of a rhyolite. This rock is the major contributor of fluoride in drinking water in Langtang area 


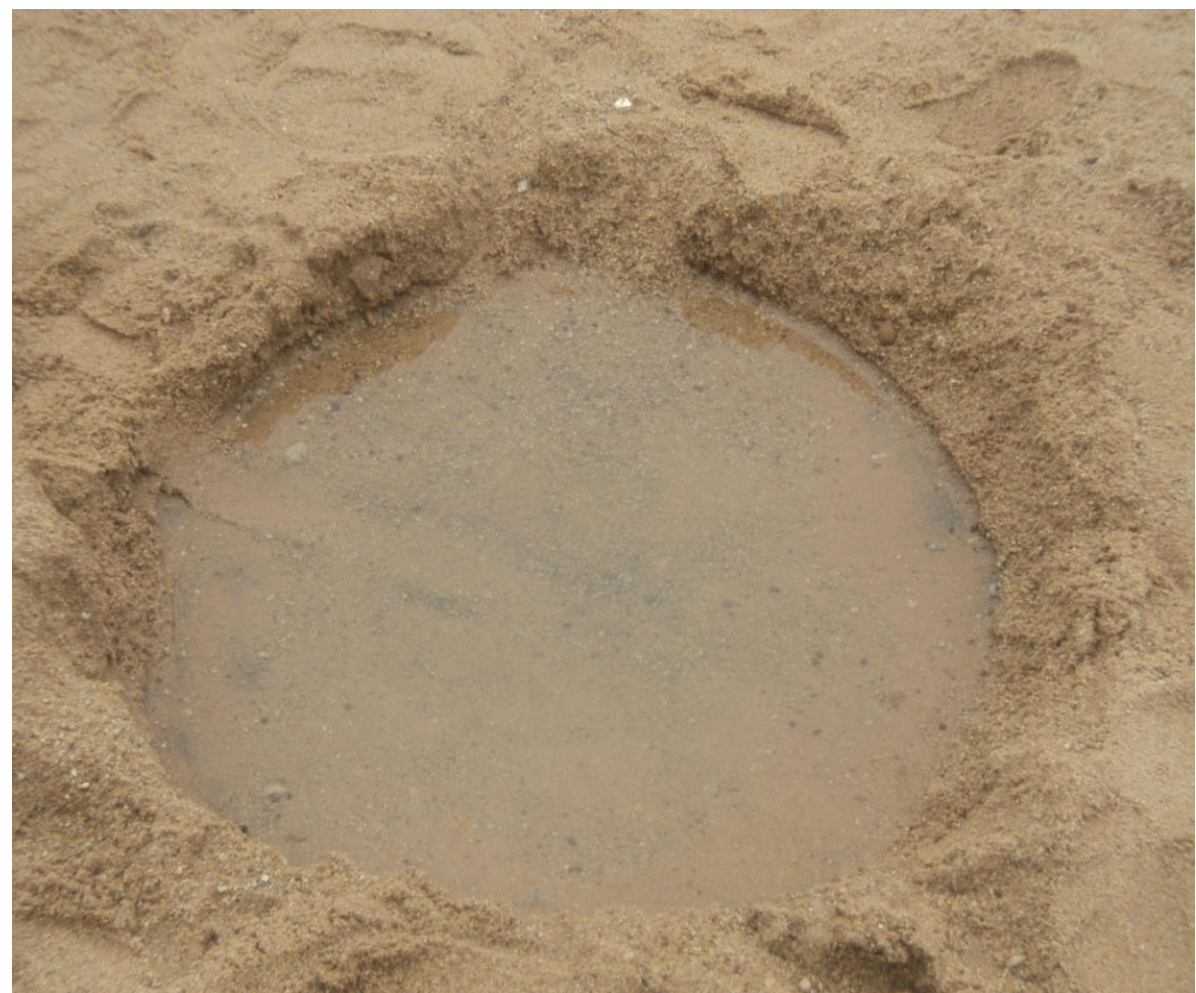

Plate II: Water holes from river sands at Bapkwai. Concentration of fluoride in this water is $0.03 \mathrm{mg} / \mathrm{l}$ in the dry season

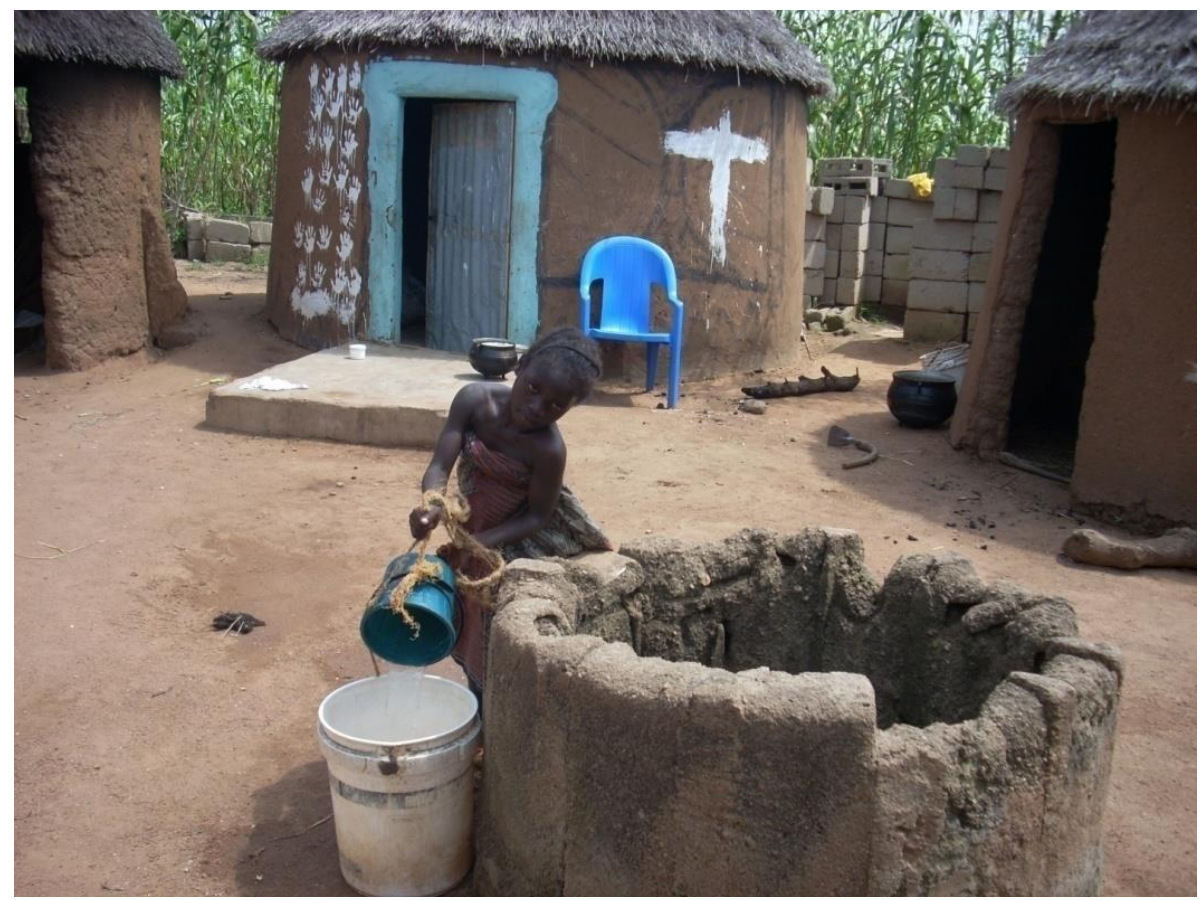

Plate III: A household hand-dug well within a community in the study area 


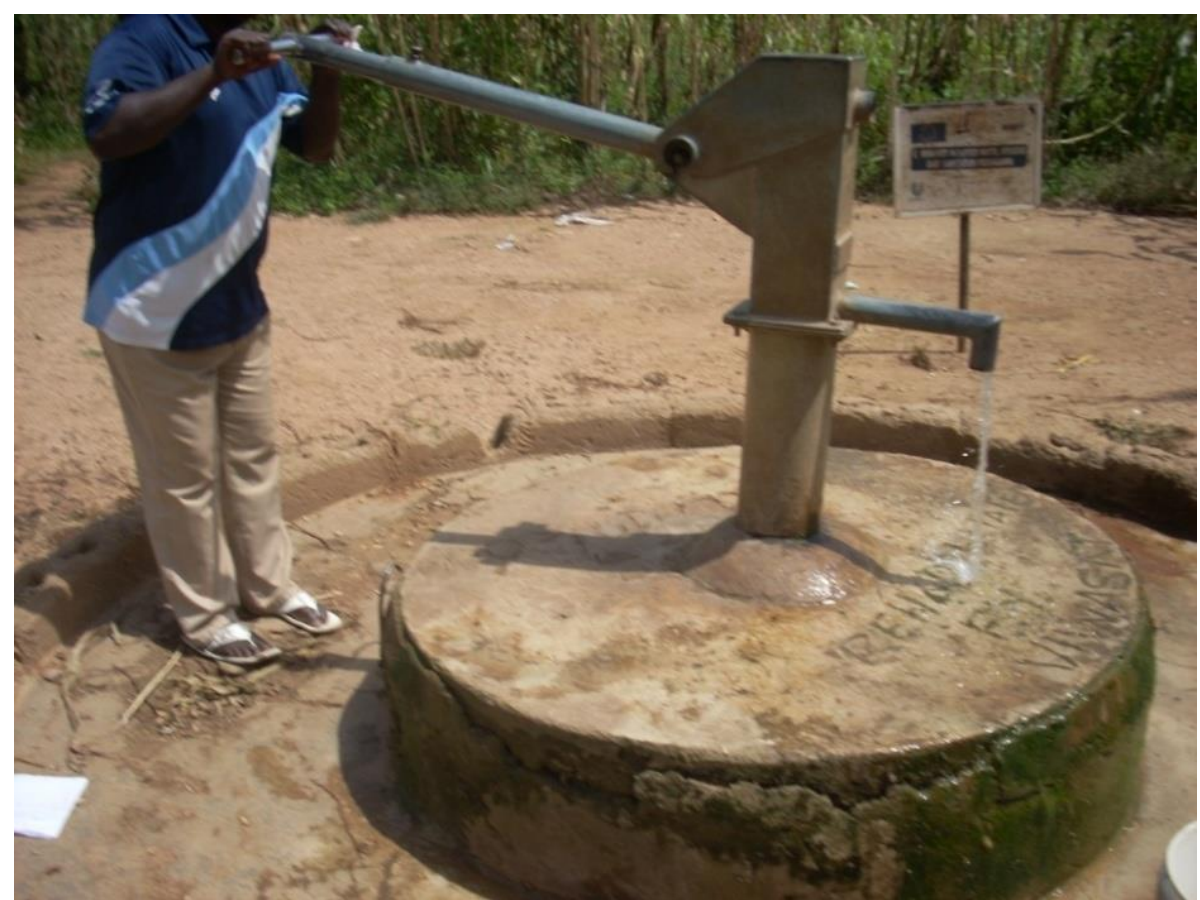

Plate IV: A community hand-dug well mounted with hand pump in the study area. This well retains sufficient water all-year round

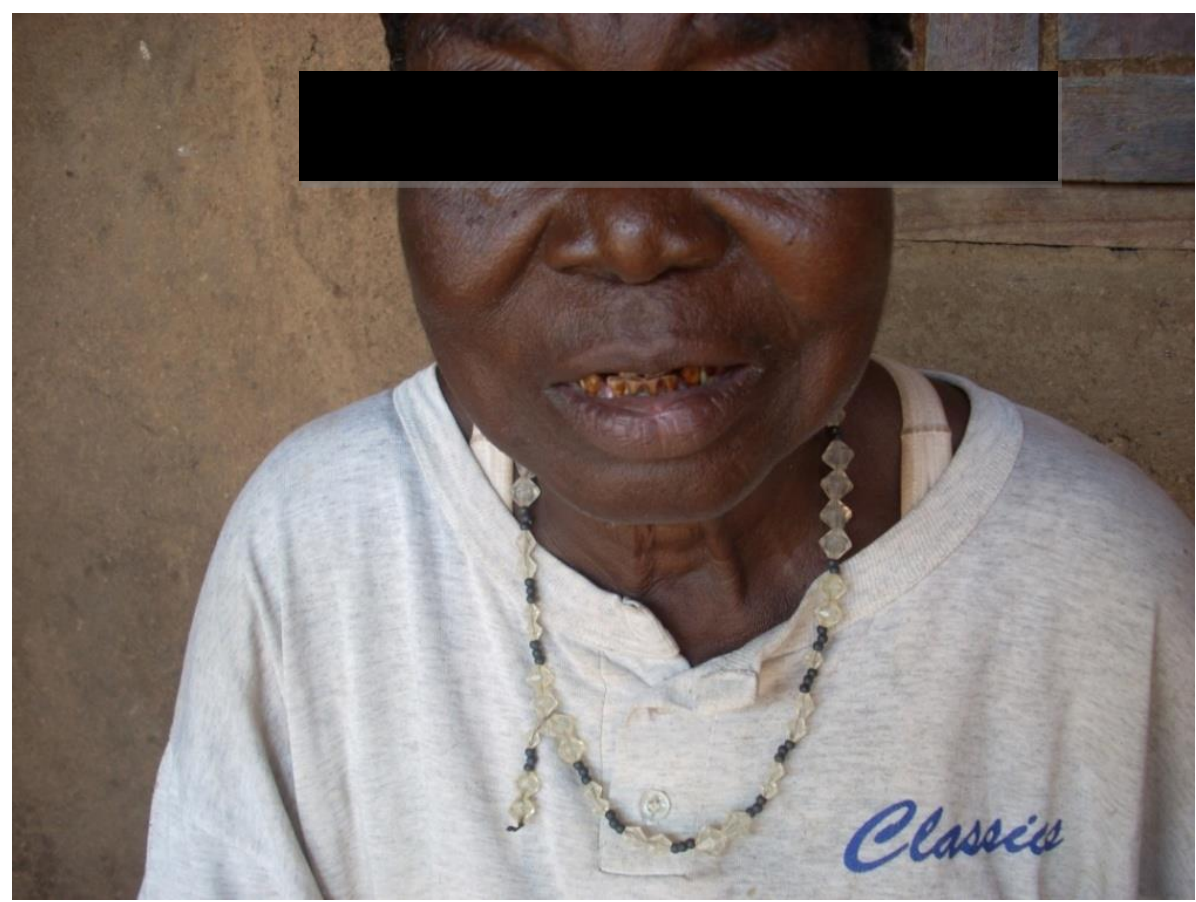

Plate V: Manifestationof dental fluorosis in an old woman from the study area aged 70 years 


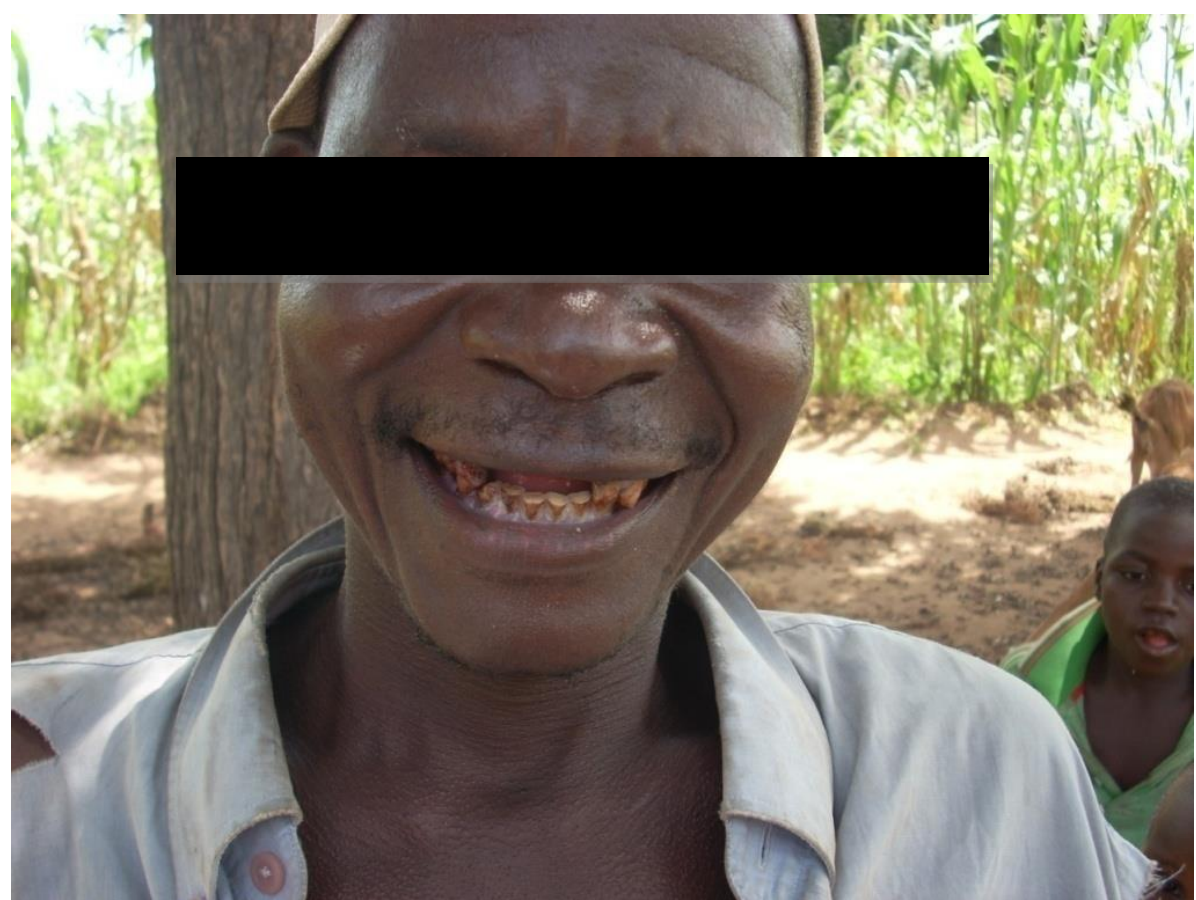

Plate VI: Manifestation of dental carries from a man aged 30 years (all the three upper incisors lost) 